\title{
An Introduction to Myself and My Current Research Interests
}

\section{Akikazu Sakudo*}

Laboratory of Biometabolic Chemistry, School of Health Sciences, University of the Ryukyus, Nishihara, Okinawa 903-0215, Japan

In December 2012 I joined "Clinical Microbiology: Open Access (CMO)" as an Editorial Board member. In this editorial, I will introduce my educational background and my previous and current research interests.

Currently, I work as an Associate Professor at the University of the Ryukyus in the field of virology. After graduating from high school, I entered college at the Tokyo University of Science. During my fourth year, I began a research project in the area of cell biology where I studied differentiation of neuronal cells (PC12 cells) [1]. During this period, I learned about prion diseases such as bovine spongiform encephalopathy (BSE), Creutzfeldt-Jakob disease (CJD) and scrapie. I subsequently entered an MS program and then a $\mathrm{PhD}$ program at the University of Tokyo (Department of Molecular Immunology, School of Agricultural and Life Sciences) to study prion proteins. In the laboratory, I performed research on "the functions of cellular prion protein in copper homeostasis and anti-oxidative defense" $[2,3]$. As a result of this research I received an award from the Japanese Society for Host Defense Research in 2006 and an award from the Japanese Society of Veterinary Science in 2009. After I moved to Osaka University, I began to perform research on near-infrared (NIR) spectroscopy as a postdoctoral scientist [4]. As a result of my NIR studies, I received the 2006 Award for best poster from the Forum of Near-Infrared Spectroscopy in Japan for our study entitled, "Bio-monitor of prion infections by nearinfrared spectroscopy”. In 2006 I received the Venture business award from Osaka University for our study entitled, "Non-invasive diagnosis of infectious diseases by near-infrared spectroscopy". I was also a recipient of the 2011 NIR Advance Award from the Japan Council for Near Infrared Spectroscopy for our project entitled, "Development of clinical laboratory test using NIR spectroscopy". After moving from Osaka University to the University of the Ryukyus, I set up a bio safety level 2 (BSL-2) animal facility in my laboratory. I recently started a new research project on gas plasma sterilization of pathogens such as viruses and prions [5]. Related to this research, I received the $1^{\text {st }}$ Nanointerface Innovative Award for our study entitled, "Interactions between $\mathrm{N}_{2}$ gas plasma and viruses in nanoscale", from the Committee of Frontier Science of Interactions between Plasmas and Nanointerfaces in 2011.

My current research interests are in the potential application of NIR spectroscopy for the diagnosis of diseases using blood and tissue samples. This technique can be used to measure triglycerides in biological samples and for the diagnosis of psychiatric and chronic fatigue syndrome (CFS) diseases [6,7]. The possibility of using noninvasive NIR analysis for diagnosis has also been examined. We found that hematocrit levels and influenza virus infection could be noninvasively analyzed using NIR spectroscopy [8,9]. In addition to these NIR studies, I am currently engaged in investigating the use of gas plasma for sterilization, disinfection and antisepsis [5]. This method has been applied to prions, which are composed exclusively of proteins and are the most difficult pathogens to inactivate. Because a conformational conversion of prion proteins is an essential step in the pathogenesis and infectivity of prions, the gas plasma treated prions were analyzed by an in vitro proliferation method (PMCA: protein misfolding cyclic amplification) in addition to an in vivo animal bioassay.

\section{References}

1. Ohuchi T, Maruoka S, Sakudo A, Arai T., Assay-based quantitative analysis of PC12 cell differentiation, J Neurosci Methods. 2002; 118, 1-8.

2. Sakudo A, Onodera T, Suganuma Y, Kobayashi T, Saeki K, et al. (2006) Recent advances in clarifying prion protein functions using knockout mice and derived cell lines. Mini-Rev Med Chem 6:589-601.

3. Sakudo A, Onodera T, Ikuta K (2007) Prion protein gene-deficient cell lines: powerful tools for prion biology. Microbiol Immunol 51: 1-13.

4. Sakudo A, Suganuma Y, Kobayashi T, Onodera T, Ikuta K (2006) Near-infrared spectroscopy: promising diagnostic tool for viral infections. Biochem Biophys Res Commun 341: 279-284.

5. Sakudo A, Shintani H. Sterilization and disinfection by plasma: Sterilization mechanisms, biological and medical applications. NOVA Science Publishers, 2011.

6. Sakudo A, Kato YH, Tajima S, Kuratsune H, Ikuta K (2009) Visible and near-infrared spectral changes in the thumb of patients with chronic fatigue syndrome. Clin Chim Acta 403: 163-166.

7. Kato $\mathrm{YH}$, Matsunaga $\mathrm{H}$, Sakudo A, Ikuta $\mathrm{K}$ (2008) Visible and near-infrared spectral changes in plasma of psychiatric patients. Int J Mol Med 22: 513-519.

8. Sakudo A, Kato YH, Kuratsune H, Ikuta K (2009) Non-invasive prediction of hematocrit levels by portable visible and near-infrared spectrophotometer. Clin Chim Acta 408: 123-127.

9. Sakudo A, Baba K, Ikuta K (2012) Analysis of Vis-NIR spectra changes to measure the inflammatory response in the nasal mucosal region of influenza $\mathrm{A}$ and $B$ virus-infected patients. J Clin Virol 55: 334-338.

Received December 26, 2012; Accepted December 26, 2012; Published December 29, 2012

Citation: Sakudo A (2013) An Introduction to Myself and My Current Research Interests. Clin Microbial 1: e102. doi:10.4172/2327-5073.1000e102

Copyright: (C) 2013 Sakudo A. This is an open-access article distributed under the terms of the Creative Commons Attribution License, which permits unrestricted use, distribution, and reproduction in any medium, provided the original author and source are credited.
} 